\title{
Liberation Theologies of the Twentieth Century: Insights for Integral Development of Africa in the Twenty-First Century
}

\author{
Samuel O. Okanlawon ${ }^{1}$
}

${ }^{1}$ Department of Religious Studies University of Ibadan, Ibadan, Nigeria.

\begin{abstract}
Development ideas and programmes in Africa generally overlook the role of religion. But contrary to this attitude, religion, in this context, Christianity, can be a catalyst to the development of Africa in the twenty-first century. The theological discourse of the twentieth century propelled progressive socio-economic and political developments. Thus, the paper examines the liberation theologies of the twentieth century and contextualizes the lessons learned from them for development in Africa and as an exemplar exercise in public theology. This is done using the historical method of research within the ambit of the theory of theological reflection. The liberation theologies affirmed the biblical ethos of liberation for all people under God with a focus on poverty, racism, and gender inequality. They became the platform for galvanizing efforts towards humanization and the betterment of people's lives. Their propositions can be integrated into thinking and quest for development in Africa.
\end{abstract}

\author{
Correspondence: \\ Samuel O. Okanlawon \\ Email: so.okanlawon@mail. \\ ui.edu.ng \\ Publication History \\ Received 30th June 2020, \\ Accepted 8th January 2021, \\ Published online 18th \\ January 2021.
}

Keywords: Theology, Liberation, Liberation Theologies, Development, Feminist, Africa, Black, Public Theology.

(C) 2021 The Author(s). Published and Maintained by Noyam Publishers.

This is an open access article under the CCBY license (http://creativecommons.org/licenses/by/4.0/).

\section{INTRODUCTION}

Africa is a continent endowed with immense natural and human resources as well great cultural, ecological and economic diversity, yet, it remains underdeveloped. Despite the various efforts made by African nations and the United Nations to develop Africa, the present situation in Africa calls for a new and distinctive approach to development. The ideas about development generally overlook the role of religion or assumed that religion should be relegated to the realm of private belief in the face of secularism and liberalism. At times, religion is considered an obstacle to development. Contrary to these ideas, religion, in the context of Christianity, could be a catalyst to the development of Africa in the twenty-first century.

In the twentieth century, the theological discourse was premised on the contextualizing nature of biblical revelation. The central question in this paper is whether or not the theological discourse of the twentieth century led to progressive development and what lessons can be drawn for contemporary Africa? The concept of development adopted here does not pertain to economic indices only, but the coagulation of all human activities that affect all aspects of human lives. Some African scholars such as Stan Chu Ilo, Idara Otu, and Agbonkhianmeghe Orobator ${ }^{1}$ have worked on African theology of development. But these studies have not focused extensively on the rich lessons from the liberation theologies of the twentieth century. So, the main preoccupation of this paper is to contextualize these lessons for Africa's development.

From this backdrop, this article has as its central theme, the liberation theologies of the twentieth century as a framework that could guide Africans in both the praxis and attitudes that support development. Thus, the pertinent issues arising from twentieth-century liberation theologies (preferential option for the poor - Latin America, rejection

\footnotetext{
Stan C. Ilo, The Church and Development in Africa: Aid and Development from the Perspective of Catholic Social Ethics,2nd ed.(Eugene: Pickwick Publications, 2014); "Africae Munus and the Challenges of a Transformative Missional Theological Praxis in Africa's Social Context", Transformation

31, no. 2 (2014):116-131; Idara Otu, Communion Ecclesiology and Social Transformation in African Catholicism (Eugene: Wipf and Stock Publishers, 2020); Agbonkhianmeghe, “Caritas Veritate and Africa’s Burden of (Under)development”, Theological Studies 71(2010):320-334.
} 
of racism - Black Liberation Theology, and Gender equality - Feminist Liberation Theology), the observation of the parameters for theologizing in these periods, and the culminating effects for societal development is the focus of this article. The interest in this work is not to critique the theological framework of the liberation theologies. In the twentieth century, the experiences of the poor, blacks and women served as the fundamental touchstone and theological writing aimed at deconstructing peculiar forms of oppression.

The discussion in this work will be done within the scope and ethos of public theology. As William Storrar states: "public theology is a collaborative exercise in theological reflection on public issues, which is prompted by disruptive social experiences that call for a thoughtful and fruitful response". ${ }^{2}$ This is done using the historical method of research within the ambit of the theory of theological reflection.

The historical method involves the use of secondary sources of data such as published books, journal articles and statistical data derived from written documents. The theory of theological reflection posits that the exploration of individual and corporate experience in conversation with the wisdom of religious heritage, can transform social structures and institutions and at fuller personal integration and conversion. ${ }^{3}$ The propositions made by the liberation theologies are geared towards systematic change and reorientation, which can be integrated into thinking and quest for development in Africa.

The propositions of the liberation theologies can be applied to the socio-economic and political framework of African society. This adumbrates public theology as a phenomenon of theology in a globalized world. ${ }^{4}$ Ronald Sider, one of America's activist evangelical theologians of the twentieth century states: "the liberation theologies were the most significant theological development of the twentieth century... These theologies attempted to fundamentally rethink theology from the standpoint of the oppressed." "The challenge in the twenty-first century is to consider the relevance of these theologies as a springboard for development.

\section{Liberation Theology: A Description}

The term "liberation theology" can be attributed both to Gustavo Gutierrez, a Peruvian priest in Latin America and James Cone in the United States, each of whom used the term in $1968 .{ }^{6}$ Liberation theology emerged in a context of political, social, and economic change in the 1960s, and 1970s. It was a new calling for the church in pursuit of social justice, equality and defense of human regards. Liberation theology is most often associated with twentieth-century Roman Catholicism in Latin America, but it is a family of theologies that include Latin Americans, Blacks, and feminist groups. ${ }^{7}$ Thus, it is about theologizing with and for the poor, the oppressed and marginalized in societies as well as, against all forms of social injustices.

Liberation theology arose as a theological response to concrete situations of oppression. For Muskus, liberation theology is unashamedly a class theology because it theologizes from the perspective of the oppressed. ${ }^{8}$ Liberation theology, as opined by Gutierrez, understands theological discourse as a critical reflection on practice in the light of faith, which is the same as saying that it is a reflection from the perspective of following Jesus. ${ }^{9}$ Liberation theology has two basic principles: first, it recognizes a need for liberation from any kind of oppression- political, economic, social, sexual, racial and religious oppression; second, it asserts that theology must grow out of the basic Christian communities and should not be imposed from above. ${ }^{10}$ That is, this kind of theology is a reflection of the fact that human liberation has to be part of the Christian understanding of salvation.

Liberation theologians approach the Bible with the view that God speaks particularly through the poor. Thus, they adopt a Marxist view of social analysis. Liberation theologians have in various ways shown a preference for socialism over capitalism. ${ }^{11}$ Historically, the struggle for social and political liberation, spearheaded by popular movements and Christian groups, laid the theoretical foundation for a theology of liberation. This was followed by theological reflections about pastoral problems affecting the general populace by church people and theologians.

\footnotetext{
William Storrar, “A Kairos Movement for Public Theology,” International Journal of Public Theology 1, no. 1 (2007): 6.

John Trokan, "Models of Theological Reflection: Theory and Praxis", Catholic Education: A Journal of Inquiry and Practice 1, no. 2 (1997): 149.

Frederike van Oorschot, "Public Theology Facing Globalization", in Contextuality and Intercontextuality in Public Theology, edited by Heinrich BedfordStrohm, Florian Hohne and Tobias Reitmeier, (Berlin: LIT Verlag, 2013), 226.

Ronald J. Sider, “An Evangelical Theology of Liberation”, Christian Century, (1990), accessed December 5, 2017, http://www.religion-online.org.

6 Craig L. Nessan, "Liberation Theologies in America", in Oxford Research Encyclopedia of Religion (Oxford: Oxford University Press 2017), 21, accessed February 8, 2018, http://www.doi.10.1093/acrefore/9771799340378.013.493.

Ron Rhodes, "Black Theology, Black Power and Black Experience", Christian Research Journal 13, no. 4 (1991): 28.

Eddy Muskus, "Liberation Theology: Its Origin and Early Development", Foundations 29, no. 30 (1992): 37.

Gustavo Gutierrez, "Memory and Prophecy", in The Option for the Poor", edited by Daniel G. Groody, (Notre Dame, Indiana: University of Notre Dame Press, 2007), 33.

10 Marian Hillar, "Liberation Theology: Religious Response to Social Problems", in Human and Social Issues: Anthology of Essays, edited by Marian Hillar and H. R. Leuchtag, (Houston: American Humanist Association, 1993), 40.

11 Peter Burns, "The Problem of Socialism in Liberation Theology", Theological Studies 53 (1992): 493.
} 


\section{LATIN AMERICAN LIBERATION THEOLOGY}

According to Craig Nessan, Latin American liberation theology evolves as the most original and compelling theological movement from the developing world in the modern period. ${ }^{12}$ Latin American liberation theology proposes to fight poverty by addressing its alleged source: sin. In so doing, it explores the relationship between Christian theology and political activism, especially concerning social justice, and human rights. It perceives theology from the perspective of the poor and the oppressed.

The origins of Latin American liberation theology can be traced to the base ecclesial communities of Brazil in the 1950s and 1960s and in the second conference of the Latin American Bishops, which was held in Medellin, Colombia in 1968. Gustavo Gutierrez is one of the prominent proponents of liberation theology in Latin America. Some of the precursors to Latin American liberation theology include socio-economic deprivation of the majority of the people, political injustice, alignment of the ecclesiastical establishment with the rich, and radicalization of pastoral agents. Latin American liberation theologians interpreted the Bible as a call to action against poverty and the sin engendering it, to effect Jesus Christ's mission of justice in this world.

The theological discourse of Latin American liberation has hybridized with contributions from sociological and Marxist thinking. From a Christian perspective, it seeks to unmask Latin American's situation of exploitation, oppression and neo-colonization of the twentieth century. For Latin American liberation theologians, God is not impassive but dynamically involved on behalf of the poor and downtrodden. Since God stands against oppression and exploitation, those who follow God must do likewise. ${ }^{13}$

\section{Black Liberation Theology}

Black liberation theology originated in some black populated churches in the United States of America and later in other parts of the world. It refers to a theological perspective that contextualizes the Christian gospel and its values in an attempt to help those of African descent overcome oppression. It especially focuses on the injustice committed against African Americans and black South Africans during American segregation and apartheid respectively.

The term "black" in Black Liberation Theology is used as a positive identifier as opposed to the negative term "non-white". That is, "black" refers to all victims of racism. So, it was not about the pigmentation of the skin but attitudes of the mind. It originated as a response to white racism in the United States following the activism of the civil rights and Black Power movements as theologians began to reflect critically on the role of Christian teaching in light of black experiences of suffering and oppression. ${ }^{14}$

In South Africa, Black Liberation Theology was born in the context of the South African liberation struggle and synonymous with the apartheid struggle. It was popularized by Basil Moore, a Methodist theologian in South Africa, and it developed in parallel with the Black Consciousness Movement. Black Liberation Theology in South Africa drew heavily from Steve Biko's philosophy of black consciousness. Mokgethi Motlhabi, a theologian in South Africa, notes that in content and outlook, it was situational, that is, South African and not American. ${ }^{15}$ Thus, the black theologians in South Africa did not present a theology muddled up in a victimization mentality. As pointed out by Timothy van Aarde, it was focused on the rediscovery and reclamation of human dignity and identity as against the liberation theology of South America, which focused on liberating people from oppressive structures. ${ }^{16}$

Black Liberation Theology seeks to liberate people of colour from multiple forms of political, social, economic, and religious subjugation. Black liberation theologians criticize and seek to reconfigure Christian theology to achieve the dismantling of structural racism by drawing upon scripture, church history, theological resources, black religious traditions, and black culture. Thus, God's immanence is stressed over his transcendence.

The period that gave rise to Black Liberation Theology is characterized by an entrenched Christianization of slavery of the eighteenth century and white interpretation of Christianity that encouraged marginalization and oppression of the Blacks. Most proponents of Black Liberation Theology like James Cone, Basil Moore, Allan Boesak and Robert Beckford base much of their liberationist theology on God's deliverance of Israel from Egypt in the Book of Exodus; the person of Jesus depicted in Luke's Gospel; the messages and personalities of biblical prophets like Isaiah, Jeremiah, Ezekiel, Daniel and others, who were frequent critics of the status quo in Israelite history. James Cone, one of the major proponents of Black Liberation Theology in the United States of America, believed that the New Testament revealed Jesus as one who identified with those suffering under oppression, the socially marginalized and the cultural outcasts. He further argued that from a theological perspective, Jesus revealed himself as black to disrupt and dismantle white

\footnotetext{
2 Craig Nessan, The Vitality of Liberation Theology (Eugene: Pickwick, 2012), 7.

3 Jason Berry, "El Salvador's Response to Liberation Theology", The Washington Post 4, no. 10 (1989): 25.

4 Nessan, "Liberation Theologians in America", 2.

Mokgethi Motlhabi, African Theology/Black Theology in South Africa: Looking Black, Moving On (Muckleneuk: Unisa, 2008 ), 22.

Timothy van Aarde, "Black Theology in South Africa - A Theology of Human Dignity and Black Identity", HTS Theological Studies 72 , no. 1 (2016): 4.
} 
oppression. ${ }^{17}$ Black Liberation Theology brought to the fore the augmentations to contest institutionalized racism.

\section{Feminist Liberation Theology}

Feminist liberation theology grew out of the economic, political, social, physical, psychical and intellectual destruction occurring in the lives of women. ${ }^{18}$ It is an offshoot of the women's liberation movement of the 1960s that demanded a restructuring of societal institutions and a redefinition of cultural images and roles of women and men, to make women autonomous human persons and achieve economic and political equality. ${ }^{19}$ It emerged out of the experiences of women dealing with a long history of subordination, destruction, and oppression in response to hierarchical patriarchy. ${ }^{20}$

One could describe Liberation theology of feminists as an attempt to re-conceptualize and transform Christian theology from a feminist perspective to eliminate the cultural sexism and ecclesia patriarchalism that exists among theologians and within ecclesial institutions. It demands to bring women's perspectives into theology and pushes forward what Elizabeth Fiorenza terms a "whole theology" 21 because the human understanding of God requires the theological participation of both sexes. Feminist theologians draw motivation from Galatians 3:28 which affirms that, within the Christian community, "there is neither Jew nor Greek, there is neither bond nor free, there is neither male nor female: for ye are all one in Christ Jesus". ${ }^{22}$ Ursula King opines that Feminist Liberation Theology is concerned with the liberation of women from oppression, guided by the principles of seeking to achieve the full humanity of women. ${ }^{23}$ There is a diversity of approaches among feminist theologians. However, the one thing that is outstanding and common in Feminist Liberation Theology is that it represents a critique of patriarchy. ${ }^{24}$

The methodology of feminist theologians involves both recovery and reinterpretation of the Bible and Christian tradition. Mary Ruether asserts: "this process has three interrelated aspects: a critique of misogyny and androcentrism in the biblical and theological tradition; recovery of alternative, prophetic, egalitarian traditions; and envisioning all the theological symbols in an egalitarian, justice-making way." 25

Feminist liberation theologians go about achieving their task by engaging in a hermeneutical method that highlights positive female themes in the Bible and church tradition, which encourages gender inclusiveness and elevates the humanity of the females. Carolyn Osiek identifies three approaches to feminist biblical interpretation: the Bible is part of human history and is used as an instrument of power, and hence, the church should recognize this and eliminate the abuse; biblical interpretation is not just an abstract academic enterprise, hence, understanding the Bible should, therefore, happen in constant interaction with the experience of faith communities; and that biblical texts should be interpreted and understood in light of the specific situations people find themselves because biblical texts originated within specific traditions and continue to function within specific traditions.$^{26}$ Furthermore, feminist liberation theologians emphasize the personhood of God as both father and mother.

\section{Influences of the Liberation Theologies of the Twentieth Century on Societal Development}

Richard Pace stated that in Gurupa, Brazil, the Roman Catholic Church employed the Liberation Theologies to defend indigenous tribes, farmers, and extractors from land exploration by federal or corporate forces. ${ }^{27}$ This led to the formation of the church - supported communidad(e) ecclesial de base (CEBs). ${ }^{28}$ The CEBs introduced new social ideas and democratic methods, which led to many participants' active involvement in popular movements of Brazil that worked for progressive social change. For instance, the CEBs initiated a health programme in Nova Iguala, a municipality in Rio de Janeiro, Brazil that organized the population to remedy widespread malnutrition, open sewers, and other health hazards. This neighborhood initiative became a mass movement in nearly every Brazilian neighborhood.

Another instance referenced by Pace concerning the CEBs of Nossa Senhora de Fatima, a municipality of Santa Maria, Rio Grande de Sul, Brazil, in which a community of twenty-four families of farmers, timber extractors, and traders resisted an extra-region timber extraction firm. He states that the community negotiated an agreement with the firm that gained them a higher standard of living that included imported goods, increased food availability, and access

\footnotetext{
James H. Cone, A Black Theology of Liberation (New York: Orbis Books, 1990), 56-57.

Jana Opocenska, "Feminist Theology”, Indian Journal of Theology 37, no. 2 (1995): 40.

Elizabeth S. Fiorenza, "Feminist Theology as a Critical Theology of Liberation", Theological Studies 36, no. 4 (1975): 606 - 607.

Nessan, "Liberation Theologies in America", 7.

Elizabeth Fiorenza, "Feminist Theology as a Critical Theology of Liberation", 615.

Elizabeth Fiorenza, "Feminist Theology as a Critical Theology of Liberation", 619.

Ursula King, Feminist Theology from the Third World (New York: Orbis Books, 1994), 3.

Patriarchy is applied to systems and attitudes of dominance that result in the structures and ideologies of racism, sexism, classism, and militarism (Sharon Ringe, "Feminist Theology and the United Church of Christ", in Theology and Identity, edited by Johnson and Hambrick-Stowe, 118).

Rosemary Ruether, Sexism and God-Talk, (Boston: Beacon Press, 1973), 19.

6 Carolyn Osiek, "The Feminist and the Bible: Hermeneutical Alternatives", HTS Theological Studies 53, no. 4 (1997): 956-966.

Richard Pace, "Social Conflict and Political Activism in the Brazilian Amazon: A Case Study of Gumpa", American Ethnologist 19 (1992): $711-730$.

28 The CEBs are small grassroots, lay groups of the poor or the ordinary people, comprising of 10 to 30 members, meeting to pray, conduct Bible studies, and wrestle consistently with social and political obligations in their settings.
} 
to health care. ${ }^{29}$ Liberation theology fortified small-farmer activism. Manuel Vasquez reveals that the social and political impact of the CEBs can be viewed in terms of initial consciousness-raising, the motivation for movement, the sense of community they developed, the experience of grassroots democracy, the direct actions they engaged in, and finally, directly political actions. ${ }^{30}$

Integral mission or holistic mission, in relation to Latin American liberation theology came forth from the activities of liberation theologians in Spain. ${ }^{31}$ Generally, the following has been pointed out as the accomplishment of liberation theology in Latin America: "enable us to hear the voice of the poor and to allow that voice to challenge our values and beliefs, even as it highlights our participation in structures and system that oppress others; presented new theological perspectives that open new ways of speaking about the human person, community, justice, the structures of the world in which we live, and hope for the future; and clamour for the situatedness of all knowledge, that is ideology critique of theological propositions." 32

Black liberation theology points out the scope and pervasiveness of racism in modern society. It affirmed the dignity of humans and the uniqueness of the identity of black people by confronting the imbalance of power and abusive power structures. In the United States of America, Black Liberation Theology exposed the elitism and ecclesiasticism, which had shaped white Christianity and forced the American people into broader categories to understand the Christian heritage. ${ }^{33}$ While in South Africa, Black Liberation Theology not only contributed greatly to the struggle to end the structured sin of apartheid, it also led to the development of a national reconciliation that led to the building of a new South Africa. ${ }^{34}$

In another vein, the Black Liberation Theology movement in South Africa enabled black clergy and black Christians to engage in the political struggle for liberation as Christians. The clamor was no longer for liberation from racist oppression, but social justice and a more equal society. Furthermore, the emergence of Black Liberation Theology challenged the status quo of Christian theological thought in Christianity and brought about the major reassessment of white "mainstream" theology. In Rhodes' opinion, the following are Black Liberation Theology's important contribution: "it has reminded us that theology must find practical expression in society if it is going to meet the needs of contemporary Christians, hence, theology is not academic but practical; it has reminded us that God is involved with the people in real-life situations; it has focused our attention on the need to reach out to others in the church and in the society who are suffering, and it serves as an indictment against the racist views that have often been present among white people." ${ }^{\prime 35}$

Feminist liberation theology has put on the front burner of theological discourse the need for a richer and broader language of divinity that genuinely transcends the gendered "Godfather" description of God. As Muers states, feminist theologians express concern about how God is named and imagined in male terms and considered this as idolatrous because it leads to a misdirection of worship and a distortion of human relationships. ${ }^{36}$ This has encouraged a gender-neutral naming and imagining of God both in the academy and church contexts, and the challenge of the hierarchical - patriarchal societal structure that has paved way for societal equality in interpersonal relations between both sexes.

Through a critical re-reading of the biblical texts, feminist theologians have exposed the symbolic structures that support the oppression of humans and the denigration of femaleness within these texts and Christian theology. As revealed in the final reports of the World Council of Churches' "Decade of solidarity with women" in 1997, Feminist Liberation Theology has increased the awareness of women in the Western world of the need to enact solidarity with the women of the Third World, thus reducing minimally the problems of marginalization that beset Feminist Liberation Theology. ${ }^{37}$ According to Muers, the encounter of theology with feminist movements and feminist tools of analysis have changed the face of theology. Besides, feminist theological analyses have questioned the implication of theology in gender-based patterns of domination. ${ }^{38}$

\footnotetext{
29 Pace, "Social Conflict and Political Activism in the Brazilian Amazon", 731.

30 Manuel Vasquez, The Brazilian Popular Church and the Crisis of Modernity (Cambridge: Cambridge University Press, 1998), 50-60.

31 Integral mission is used to describe an understanding of Christian mission, which embrace both evangelism and social responsibility. It affirms the importance of expressing the love of God and neighbourly love through every means possible.

32 Rebecca Chopp and Ethna Regan, "Latin American Liberation Theology", in The Modern Theologians: An Introduction to Christian Theology Since 1918, 3rd ed., edited by David F. Ford and Rachel Muers (Oxford: Oxford Publishing, 2005), 480.

33 John Carey, "What Can We Learn from Black Theology?" Theological Studies 35, no. 3 (1974): 521.

34 van Aarde, Black Theology in South Africa, 3.

Rhodes, "Black Theology, Black Power, and Black Experience", 7.

36 Rachel Muers, "Feminism, Gender, and Theology", in The Modern Theologians: An Introduction to Christian Theology, edited by D. F. Ford and Rachel Muers (Oxford: Blackwell Publishing, 2005), 431-450.

37 Muers, "Feminism, Gender, and Theology", 448.

38 Muers, "Feminism, Gender, and Theology"447.
} 


\section{The Implication of the Liberation Theologies for Development in Africa in the Twenty-First Century}

The term "liberation" belongs to the socio-economic context of development because it was first used in the context of socio-economic development to designate a more embracing approach to development than the approaches people are familiar with. This new understanding of developments was what Gutierrez called a "total social process" ${ }^{39}$ The advocacy of the liberation theologians targeted at uprooting the economic, political and social structures responsible for poverty, injustice and gender discrimination in human societies relates to the notion of development. This is because the concept of development calls attention to the application of the "human side" to solving societal problems.

First and foremost, these theologies of liberation remind Africans that theology must find practical expression in society if it is going to meet the needs of the twenty-first century and beyond. They likewise bring to the fore the exigency of reaching out to others who are suffering because God is involved with his creatures in real-life situations. They reintroduced the fact of human experience as the starting point of a credible Christian theology.

More so, the hermeneutics of the liberation theologies brought the socio-economic and political contexts into critical dialogue with Scripture and other sources of Christian theology. In Botha's words, 'it is the kind of hermeneutics that facilitates a constant re-describing of reality towards renewal'. ${ }^{40}$ In this way, Christian theology is informed by social analysis and lifts it from the realm of theoretical postulations to the realm of praxis. This is a lesson for those who do theology or are engaged in the theological enterprise in Africa. Since every theology in itself is developed in a context, Christian theologians in Africa must continue the tradition of engaging theology for the development of humans and the society, or else Christian theology loses its ongoing relevance.

Also, the liberation theologies emphasize the necessity to recognize the distinctiveness of the existence of every people group and to likewise recognize the plurality of cultural experiences within the African society. The identity of each constituent member of the society must not be suppressed nor considered irrelevant in any given society. It is a known fact that many African countries are currently divided along ethnic, tribal and racial lines. This has led to wars and the clamor for war. But recognition of the distinctiveness and right to existence of every person will lead to integration in Africa, which is a veritable precursor to development. Full recognition of personhood will replace oppression in society. For instance, the quest of Black Liberation Theology is more of the recognition of the identity of every group of people. No one has the right to suppress the other. This perspective is urgent for Africa and will minimize the inter-ethnic wars and civil unrest in Africa. The Rwandan genocide, Sudan wars, and ethnic agitations in Nigeria are examples.

In another vein, there is a strategy that the liberation theologies depict what can serve as a resource for development in Africa. The liberation theologies enabled the oppressed to come together, to understand their situation through the process of conscientization, discover the causes of their oppression, organize themselves into movements or pressure groups, and then act in a coordinated manner to reverse their oppression situations.

Thus, Africans, who suffer one oppression or the other can form alliances, push forward their quest for socioeconomic or political justice and then, set machinery in motion to achieve this. These pressure groups need to engage in the conscientization of both the oppressed and the oppressor. The aim of conscientization is not to present the oppressed as a victim or to insinuate powerlessness and hopelessness against social, economic or structures built to perpetuate the oppression. The conscientization process involves both reflection and action. ${ }^{41}$ Reflection creates an awareness of the oppressive situation(s), while action focuses on developing strategies to achieve the needed change and taking concrete steps to change their circumstances.

Furthermore, the culture of individualism that pervades the African society and which prevents her indigenes from being connected to others is challenged by the proposition of the liberation theologies considered. Humanity is challenged to think and talk about the common good and to avoid the dangers of consumerist and capitalist welfare. On the other hand, mankind is challenged to look at Africa as a post-racial society where tribal and ethnic racism is no longer entrenched among the people. Outside Africa, Africans battle with inter-racism, but within Africa, they are faced with intra-racism. The liberation theologies provide the resource to counter this form of social sin - something contrary to God's will and injurious to the ethos of good neighborliness.

Again, the salvation proclaimed by some Christian denominations in Africa, which is focused on only the "salvation of souls" is no longer adequate for the African context. The liberation seen in the Old Testament and the life, work and teaching of Jesus Christ in the Gospels is one that involved liberation in all aspects of life - social, economic, political and spiritual. Therefore, the liberation theologies lead people to a critical awareness of their impoverished

\footnotetext{
39 Gustavo Gutierrez, A Theology of Liberation (London: SCM Press, 1974), 24.

40 Nico Botha, “An Encounter Between Black Theology and Reformed Theology: The Involvement of Govender, Mazamisa, Mofokeng and Ntoane”, Studia Historiae Ecclesiasticae 41, no. 2 (2015): 81.

41 James D. Allen, Jr., "The Intersection of Liberation Theology, Structural Social Work and Empowerment Practice", Paper presented at the Third North America Conference on Spirituality and Social Work, June 2008, accessed December 21, 2016, http://www.stu.ca/spirituality/documents/JohnAllen_The Intersection of Liberation Theology.pdf.
} 
situation and this awareness is meant to lead to action for improving their condition. The people can no longer take a back seat in the affairs of the state while expecting leadership to initiate the necessary development.

Invariably, these liberation theologies are vocal oppositions to exploitation and oppression of the majority by the minority and make a case for socio-economic justice. Through their theological principles, they provoke the church and academy to pay attention to the needs of the oppressed, and to speak of God and God's reign in solidarity with those who live in these times. Also, these liberation theologies, like public theology, demand that the truth claims expressed or implied in religious faith and witness must engage and be relevant in the public sphere. This is in tandem with Smit's assertion that public theology, as a paradigm, is a generic description of all contextual attempts to deal with the relationship between faith and public life. ${ }^{42}$

\section{CONCLUSION}

The examined liberation theologies affirmed the biblical ethos of liberation for all people under God with a focus on poverty, racism and sexism, respectively. These liberation theologies became the platform for galvanizing efforts towards humanization and the betterment of people's lives by making propositions geared towards systematic change and reorientation. These propositions can be integrated with thinking and quest for development in Africa.

The liberation theologies resonate with the fact that the matter of faith should not be limited to the confines of religious institutions, but that faith personalities and communities can play a deeper transformational role in upgrading, challenging or changing ineffective social, economic, racial, or value systems; enhancing local best practice and capacity - building for development. This aligns with the submission of many public theologians that theological reflection must be public-oriented and Christian theology should play a significant role in public discourse.

In as much as one must not choose the extreme application of the liberation theologies proposition, which advocate for the killing of the oppressor, yet, the biblical basis for aiding the poor and oppressed cannot be denied. The liberation theologies challenged the culture of individualism and encouraged people to think and talk about the common good and provided resources to counter poverty, racism and gender inequality by elevating discourse on personhood and humanity as God's creature.

\section{ABOUT AUTHOR}

Samuel Oluwatosin Okanlawon holds a PhD in Christian Theology from the University of Ibadan, Ibadan, Nigeria. He lectures courses in Christian Theology in the same department, both at the Undergraduate and Postgraduate levels. He is the Editor of the Nigerian Association for Christian Studies (NACS) that publishes the Nigerian Journal of Christian Studies and a member of the Editorial Board of International Journal of Religion and Traditions. His research interests are in the theological interpretation of issues within socio-ecclesiological contexts, and how these issues can be situated within the framework of the complete biblical revelation encompassing the Old and New Testaments with particular reference to Nigeria and Africa at large. And he has published eighteen (18) articles concerning his research interests.

\section{BIBLIOGRAPHY}

Allen, Jr., James D. “The Intersection of Liberation Theology, Structural Social Work and Empowerment Practice"(2008). Accessed December 21, 2016.

http://www.stu.ca /spirituality/documents/JohnAllen-The-Intersection-of-liberation-Theology.pdf.

Berry, Jason, "El Salvador's Response to Liberation Theology". The Washington Post 4, no. 10 (1989): 23-26.

Botha, Nico. "An Encounter between Black Theology and Reformed Theology: The Involvement of Govender, Mazamisa, Mofokeng and Ntoane”. Studia Historiae Ecclesiasticae 41, no. 2 (2015): 69-81. https://doi.org/10.25159/2412-4265/347

Burns, Peter. "The Problem of Socialism in Liberation Theology". Theological Studies 53 (1992): 493-517.

Carey, John. "What Can We Learn from Black Theology?" Theological Studies 35, no. 3 (1974): 518-528. https://doi.org/10.1177/004056397403500306

Chopp, Rebecca and Ethna Regan. "Latin American Liberation Theology". In The Modern Theologians: An Introduction to Christian Theology Since 1918, $3^{\text {rd }}$ ed., edited by David F. Ford and Rachel Muers, 469-484. Oxford: Oxford Publishing, 2005.

Cone, James H. A Black Theology of Liberation. New York: Orbis Books, 1990.

42 Dirk Smit, "The Paradigm of Public Theology- Origins and Development", in Contextuality and Intercontextuality in Public Theology, edited by Heinrich Bedford-Strohm, Flovian Hohne and Tobias Reitmeier (Berlin: LIT Verlag, 2013), 17. 
Fiorenza, Elizabeth S. "Feminist Theology as a Critical Theology of Liberation". Theology Studies 36, no. 4 (1975): $605-626$.

Gutierrez, Gustavo. A Theology of Liberation. London: SCM Press, 1974.

"Memory and Prophecy" In The Option for the Poor in Christian Theology, edited by Daniel G. Groody, 1738. Notre Dame, Indiana: University of Notre Dame Press, 2007.

Hillar, Marian. "Liberation Theology: Religious Response to Social Problems". In Human and Social Issues: Anthology of Essays, edited by Marian Hillar and H. R. Leuchtag, 35-52. Houston: American Humanist Association, 1993.

Ilo, Stan. "Africae Munus and the Challenges of a Transformative Missional Theological Praxis in Africa's Social Context". Transformation 31, no. 2 (2014): 116-131. The Church and Development in Africa: Aid and Development from the Perspective of Catholic Social Ethics 2nd ed. Eugene: Pickwick Publications, 2014.

Otu, Idara. Communion Ecclesiology and Social Transformation in African Catholicism, 2020.

Kinast, R. Let Ministry Teach. Maderia Beach: Center for Theological Reflection, 1990.

King, Ursula. Feminist Theology from the Third World. New York: Orbis Books, 1994.

Motlhabi, Mokgethi. African Theology/Black Theology in South Africa: Looking Black, Moving On. Muckleneuk: Unisa Press, 2008.

Muskus, Eddy. "Liberation Theology: Its Origin and Early Development". Foundations 29, no. 30 (1992): 30-41.

Muers, Rachel. "Feminism, Gender and Theology". In The Modern Theologians: An Introduction to Christian Theology, $3^{\text {rd }}$ ed., edited by D. F. Ford and Rachel Muers, 431-450. Oxford: Blackwell Publishing, 2005.

Nessan, Craig. The Vitality of Liberation Theology. Eugene: Pickwick, 2012.

Nessan, Craig L. "Liberation Theologies in America". In Oxford Research Encyclopedia of Religion, 1-26. Oxford: Oxford University Press, 2018. https://doi.org/10.1093/acrefore/9780199340378.013.493

Opocenska, Jana. "Feminist Theology". Indian Journal of Theology 37, no. 2 (1995): 40-46.

Orobator, Agbonkhianmeghe. "Caritas in Veritate and Africa's Burden of (Under)development". Theological Studies 71 (2010): 320-334.

Osiek, Carolyn. "The Feminist and the Bible Hermeneutical Alternatives". HTS Theological Studies 53, no. 4 (1997): 955-967.

Pace, Richard. "Social Conflict and Political Activism in the Brazilian Amazon: A Case Study of Gumpa". American Ethnologist 19 (1992): 710-732. https://doi.org/10.1525/ae.1992.19.4.02a00050

Rhodes, Ron. "Black Theology, Black Power and Black Experience". Christian Research Journal 13, no. 4 (1991):2732.

Ringe, Sharon. "Feminist Theology and the United Church of Christ". In Theology and Identity: Traditions, Movements, and Polity in the United Church of Christ, edited by Daniel L. Johnson and Charles HambrickStowe, 117-123. New York: Pilgrim Press, 1990.

Ruether, Rosemary. Sexism and God-Talk. Boston: Beacon Press, 1973.

Sider, Ronald J. “An Evangelical Theology of Liberation”. Christian Century (1990). Accessed December 5, 2017. http://www.religion-online.org.

Smit, Dirk. "The Paradigm of Public Theology - Origins and Development" In Contextuality and Intercontextuality in Public Theology, edited by Henrich Bedford-Strohm, Florian Hohne and Tobias Reitmer, 11-23. Berlin: LIT Verlag, 2013.

Storrar, William. “A Kairos Movement for Public Theology”. International Journal of Public Theology 1, no. 1 (2007): 5-25.

Trokan, John. "Models of Theological Reflection: Theory and Praxis". Catholic Education: A Journal of Inquiry and Practice 1, no. 2 (1997): 144-158. https://doi.org/10.15365/joce.0102041997

Van Aarde, Timothy. "Black Theology in South Africa - A Theology of Human Dignity and Black Identity". HTS Theological Studies 72, no. 1 (2016): 1-9. https://doi.org/10.4102/hts.v72i1.3176

Van Oorschot, Frederike. "Public Theology Facing Globalization". In Contextuality and Intercontextuality in Public Theology, edited by Heinrich Bedford-Strohm, Florian Hohne and Tobias Reitmer, 225-232. Berlin: LIT Verlag, 2013.

Vasquez, Manuel. The Brazilian Popular Church and the Crisis of Modernity. Cambridge: Cambridge University Press, 1998. 